\title{
PREDIKSI LABA DI MASA YANG AKAN DATANG DENGAN RASIO KEUANGAN PADA PERUSAHAAN MANUFAKTUR YANG TERDAFTAR DI BURSA EFEK INDONESIA PERIODE 2010-2014
}

\author{
Winda Kurniawati \\ Pemerhati sektor Keuangan pada Perusahaan Perseorangan \\ "Swasta Mandiri" \\ Email: kurniawati.winda@gmail.com
}

\begin{abstract}
Abstrak
Tujuan laporan keuangan adalah untuk menyediakan informasi mengenai posisi keuangan, kinerja serta perubahan posisi keuangan suatu perusahaan yang bermanfaat bagi sejumlah besar pemakai dalam pengambilan keputusan ekonomi. Informasi yang disajikan dalam laporan keuangan akan lebih bermanfaat bagi pemakai jika dilakukan analisis lebih lanjut. Adapun tujuan penelitian ini adalah apakah rasio keuangan secara individual dan simultan berpengaruh terhadap laba di masa yang akan datang pada perusahaan manufaktur yang terdapat di Bursa Efek Indonesia selama periode 2010-2014. Guna mencapai tujuan tersebut, metode yang dilakukan adalah menguji validitas dan reliabilitas, asumsi klasik, dan regresi berganda.

Hasil yang diperoleh, Perputaran Aktiva Tetap (PAT), Interest Earned (TIE), dan Return On Asset (ROA) mempunyai pengaruh yang positif atau searah terhadap laba yang akan datang.
\end{abstract}

Kata kunci: Rasio Keuangan, Laba, BEI, .

\section{PENDAHULUAN}

Perkembangan dunia usaha menuntut adanya informasi sebagai dasar pengambilan keputusan bisnis dalam era globalisasi saat ini. Dalam hal ini, akuntansi ikut berperan dalam menyediakan informasi yang berguna bagi pelaku bisnis (investor). Informasi mengenai laba merupakan komponen dari laporan keuangan perusahaan. Laporan keuangan adalah salah satu informasi penting dan dapat dipercaya oleh pihak internal maupun eksternal perusahaan, karena laporan keuangan adalah sumber informasi mengenai perkembangan pada periode tertentu. Infomasi mempunyai peran yang sangat besar kaitannya dalam menanamkan suatu investasi. Informasi keuangan yang terdapat dalam laporan keuangan berupa neraca, laporan rugi laba, laporan perubahan modal dan laporan arus kas dapat dijadikan sebagai dasar dalam pengambilan keputusan ekonomi, karena informasi itu menujukkan prestasi perusahaan pada periode laporan keuangan tersebut. Sejalan dengan adanya perkembangan investasi maka peran akuntansi sebagai pemberi informasi suatu perusahaan juga meningkat. Hal ini disebabkan para penanam modal (investasi) menentukan informasi keuangan dari masingmasing perusahaan agar dapat mengevaluasi prestasi dan meramalkan prospek perusahaan di masa yang akan datang. 
Menurut Statement of Financial Accounting Concepts (SFAC) No.1, tujuan utama pelaporan keuangan adalah menyediakan informasi untuk membantu investor dan investor potensial, kreditor dan pemakai lainnya dalam membuat keputusan investasi, kredit dan keputusan sejenis secara rasional. Dalam Standar Akuntansi Keuangan (SAK) 2002 No.1 dinyatakan bahwa tujuan laporan keuangan adalah untuk menyediakan informasi mengenai posisi keuangan, kinerja serta perubahan posisi keuangan suatu perusahaan yang bermanfaat bagi sejumlah besar pemakai dalam pengambilan keputusan ekonomi. Informasi yang disajikan dalam laporan keuangan akan lebih bermanfaat bagi pemakai jika dilakukan analisis lebih lanjut. Dari analisis ini maka laporan keuangan menjadi informasi akuntansi yang dapat digunakan sebagai dasar kebijakan pengambilan keputusan. Informasi yang terkandung dalam laporan keuangan digunakan oleh investor untuk memperoleh perkiraan tentang laba dan deviden dimasa mendatang, tentang resiko atas nilai perkiraan tersebut (Wetson dan Brigham : 1990). Oleh karena itu laporan keuangan jelas sangat penting bagi investor. Investor juga dapat mengambil dan menganalisa beberapa informasi dari suatu laporan keuangan, antara lain laba (pertumbuhan laba), berbagai macam rasio laporan keuangan seperti rasio liquiditas, aktivitas, solvabilitas, dan profitabilitas guna menilai suatu perusahaan.

\section{RUMUSAN MASALAH}

1. Apakah rasio keuangan secara individual atau parsial berpengaruh terhadap laba di masa yang akan datang pada perusahaan manufaktur yang terdapat di Bursa Efek Indonesia selama periode 2010-2014?

2. Apakah rasio keuangan secara bersama-sama atau simultan berpengaruh terhadap laba di masa yang datang pada perusahaan manufaktur yang terdaftar di Bursa Efek Indonesia selama periode $2010-2014$ ?

\section{PENELITIAN TERDAHULU}

1. Indah Kurniawati (2001) meneliti mengenai kinerja manajemen perusahaan besar dan perusahaan kecil di Malaysia, Singapura, dan Taiwan menemukan bukti empiris bahwa perusahaan di negara Malaysia memiliki tingkat turnover yang lebih tinggi daripada perusahaan kecil, mempunyai tingkat likuiditas yang lebih rendah dari perusahaan kecil, perusahaan besar lebih profitable, dan solvabilitasnya lebih baik dari pada perusahaan kecil. Perusahaan di Singapura menunjukkan bahwa perusahaan besar mempunyai tingkat turnover yang lebih tinggi daripada perusahaan kecil, tetapi tingkat likuiditasnya lebih rendah daripada perusahaan kecil, rasio profitabilitas menunjukkan bahwa perusahaan besar lebih mampu menghasilkan laba tinggi daripada perusahaan kecil, tetapi tingkat solvabilitasnya kurang bagus daripada perusahaan kecil. Perusahaan di negara Taiwan menunjukkan bahwa perusahaan besar memiliki tingkat profitabilitas dan turnover yang lebih baik daripada perusahaan kecil, sedangkan tingkat likuiditas serta solvabilitas lebih kecil daripada perusahaan kecil. Dalam penentuan sampel perusahaan, diseleksi untuk menentukan perbedaan perusahaan besar dan kecil dengan berdasar pada total aktiva.

2. Tetet Fitrijanti dan Jogiyanto Hartono M (2002) menemukan bukti empiris bahwa perusahaan bertumbuh memiliki leverage dan kebijakan deviden lebih rendah relatif 
terhadap perusahaan tidak bertumbuh, perusahaan bertumbuh cenderung merupakan perusahaan besar, dan bahwa ukuran perusahaan memiliki korelasi negatif dengan kebijakan deviden. Variabel ukuran perusahaan dijadikan sebagai variabel kontrol menggunakan nilai buku total aset.

3. Nurjanti Takarini \& Erni Ekawati (2003) menganalisis rasio keuangan dalam memprediksi perubahan laba pada perusahaan manufaktur. Dari penelitian tersebut rasio produktifitas (ROE) berpengaruh signifikan $5 \%$, rasio likuiditas (WCTA) berpengaruh signifikan $5 \%$, rasio leverage (CLE) berpengaruh signifikan $5 \%$, rasio profitabilitas (NPM) berpengaruh signifikan $1 \%$, dan rasio produktifitas (NWS) berpengaruh signifikan $1 \%$, sehingga rasio ini tidak dapat digunakan untuk memprediksi laba 2 (dua) tahun ke depan.

4. Agus Endro Suwarno (2004) menganalisis manfaat informasi rasio keuangan dalam memprediksi perubahan laba pada perusahaan manufaktur tahun 1998-2002. Dari penelitian tersebut diatas menghasilkan 3 (tiga) rasio keuangan yaitu LTLSE, OPPBT, NIS tahun 1999 dapat digunakan (berpengaruh signifikan) untuk memprediksi laba tahun 2000, 3 (tiga) rasio keuangan IWC, NCNW, OPPBT tahun 2000 dapat digunakan (berpengaruh signifikan) untuk memprediksi laba tahun 2001, rasio keuangan tahun 2001 tidak dapat digunakan (tidak berpengaruh signifikan) untuk memprediksi perubahan laba tahun 2002.

5. Erni Ekawati (2004) memiliki bukti empiris bahwa memaksimalkan tingkat pertumbuhan tidak memaksimalkan profitabilitas akuntansi dan value creation (abnormal return). Dan tingkat pertumbuhan memaksimalkan profitabilitas perusahaan yang tinggi memaksimalkan nilai perusahaan. Dimana perusahaan dikelompokkan berdasarkan tingkat penjualan dalam satu tahun dibagi menjadi empat quartil, dan berargumen bahwa Q1 dianggap tingkat penjualan lebih rendah daripada Q2, Q3, dan Q4.

6. Indriati W, Y. Anni Aryani, Doddy S (2005) menganalisis kemampuan informasi keuangan memprediksi perubahan laba pada perusahaan manufaktur tahun 1993-2000 sebelum dan sesudah krisis moneter. Hasil dari penelitian tersebut di atas laba dan piutang dagang berpengaruh signifikan terhadap perubahan laba satu tahun ke depan sedangkan persediaan, operating expense, rasio laba kotor terhadap penjualan tidak berpengaruh terhadap perubahan laba sebelum krisis moneter. Setelah krisis yaitu laba, piutang dagang, operating expense, persediaan berpengaruh signifikan terhadap perubahan laba, sedangkan laba kotor terhadap penjualan tidak berpengaruh signifikan terhadap perubahan laba. Secara simultan semua informasi laporan keuangan berpengaruh signifikan tehadap perubahan laba, baik sebelum dan setelah krisis moneter. Pada masa sebelum krisis, laba dan piutang dagang berpengaruh secara positif sedangkan setelah krisis berpengaruh negatif.

7. Bambang Sutopo (2005) menganalisis perubahan laba setelah pajak tahun 2000-2003, perubahan deviden kas perusahaan tahun 2001 -2003 dan perubahan laba yang akan datang pada perusahaan manufaktur tahun 2000-2003. Perubahan laba setelah pajak yaitu perubahan laba naik yang diikuti perubahan deviden naik, perubahan laba turun yang diikuti perubahan deviden turun, perubahan laba yang tidak searah dengan perubahan deviden. Hasil dari penelitian di atas adalah perubahan laba naik, perubahan deviden naik, maka laba akan turun di masa yang datang, serta perubahan laba turun, perubahan deviden turun maka laba akan naik di masa yang akan datang. 
8. Meythi (2007) mengukur rasio keuangan mana yang paling baik sebagai prediktor risiko sistematik pada perusahaan manufaktur dan hasilnya adalah Return On Assets adalah yang terbaik untuk memprediksi resiko sistematik pada perusahaan manufaktur. Resiko sistematik adalah resiko yang melekat dan tidak dapat dihilangkan dengan melakukan diversifikasi. Sedangkan resiko tidak sistematik adalah resiko yang dapat dihilangkan dengan melakukan diversifikasi. Dan hasil dari penelitian tersebut diatas adalah Return On Assets (ROA) adalah yang terbaik untuk memprediksi resiko sistematik pada perusahaan manufaktur sektor basic dan chemical 2000-2003 karena pendapatan yang stabil dan pengelolaan asset secara efektif dan efisien akan mempengaruhi resiko sistematik.

9. Ardi Hamzah (2007) menganalisis rasio likuiditas, profitabilitas, aktifitas, dan solvabilitas terhadap Capital Gain (Loss) dan Dividen pada perusahaan manufaktur, dan hasilnya bahwa rasio liquiditas, aktifitas, solvabilitas, dan profitabilitas berpengaruh signifikan terhadap dividend yield dan tidak berpengaruh terhadap capital gain (loss) secara bersama-sama. Secara parsial rasio aktivitas berpengaruh signifikan terhadap deviden yield. Dan secara parsial rasio likuiditas berpengaruh signifikan terhadap capital gain (loss).

\section{TEORI DAN HIPOTESIS}

Akuntansi bisa didefinisikan sebagai proses pengidentifikasian, pengukuran, pencatatan, dan pengkomunikasian informasi ekonomi yang bisa dipakai untuk penilaian (judgment) dan pengambilan keputusan oleh pemakai informasi tersebut (Mamduh M. Hanafi dan Abdul Halim, 2005:27). Karena biasanya pemakai hanya bisa menampung dan menganalisis informasi yang terbatas, maka tujuan pelaporan akuntansi adalah membuat sistem pemrosesan dan komunikasi yang meringkaskan informasi perusahaan yang sangat banyak ke dalam bentuk yang bisa dipahami. Dengan demikian akuntansi bisa dipahami sebagai penghubung antara kegiatan ekonomi suatu perusahaan dengan pembuat keputusan. Analisis keuangan sangat bergantung pada informasi yang diberikan oleh laporan keuangan perusahaan. Laporan keuangan perusahaan merupakan salah satu sumber informasi yang penting disamping informasi lain seperti informasi industri, kondisi perekonomian, pangsa pasar perusahaan, kualitas manajemen dan lainnya. Laporan keuangan yang pokok yang dihasilkan yaitu neraca, laporan rugi laba, laporan aliran kas.

Laporan rugi-laba mencatat aliran pendapatan dan biaya-biaya yang berkaitan dalam suatu periode tertentu, biasanya satu tahun. Neraca merupakan potret kondisi keuangan perusahaan pada tanggal tertentu, yaitu tanggal yang tercantum di neraca (suatu snapshot kondisi keuangan perusahaan). Biasanya tanggal 31 Desember dipakai sebagai tanggal yang dicantumkan pada neraca. Itu berarti neraca merupakan gambaran kondisi keuangan perusahaan pada tanggal 31 Desember. Kondisi keuangan yang dicakup oleh neraca pada dasarnya adalah kekayaan perusahaan (aset) dan klaim atas kekayaan tersebut yang terdiri dari hutang dan modal saham. Laporan aliran kas menggambarkan aliran kas masuk dan kas keluar pada suatu periode tertentu. Laporan ini terutama untuk melihat likuiditas suatu perusahaan. Analisis common size dihitung dengan menghitung prosentase setiap item dalam neraca terhadap total aktiva, atau menghitung prosentase setiap item dalam laporan 
rugi-laba terhadap total penjualanAnalisis rasio-rasio keuangan pada dasarnya disusun dengan menggabungkan angka-. angka di dalam atau antara laporan rugi-laba dan neraca. Rasio likuiditas mengukur kemampuan likuiditas jangka pendek perusahaan dengan melihat aktiva lancar perusahaan relative terhadap hutang lancarnya (kewajiban perusahaan). Sedangkan rasio solvabilitas digunakan untuk menghitung total kewajiban (baik kewajiban jangka pendek atau jangka panjang), dan rasio likuiditas yang tidak bagus juga berpengaruh pada solvabilitas perusahaan. Rasio ini melihat beberapa aset kemudian menentukan berapa tingkat aktivitas aktiva-aktiva tersebut pada kegiatan tertentu. Aktivitas yang rendah pada tingkat penjualan tertentu mengakibatkan semakin besar dana kelebihan yang tertanam pada aktiva-aktiva tersebut. Dana kelebihan tersebut akan lebih baik ditanamkan pada aktiva-aktiva lain yang lebih produktif. Rasio ini mengukur kemampuan perusahaan memenuhi kewajiban-kewajiban jangka panjangnya. Perusahaan yang tidak solvabel adalah perusahaan yang total hutangnya lebih besar dibandingkan dengan total asetnya. Ada dua rasio yang bisa digunakan yaitu rasio Total Hutang terhadap Total Aktiva (THTA) dan Times Interest Earned (TIE). Rasio ini mengukur kemampuan perusahaan membayar hutang dengan laba sebelum bunga pajak. Rasio ini mengukur kemampuan perusahaan menghasilkan keuntungan (profitabilitas) pada tingkat penjualan, aset, dan modal saham tertentu. Mengukur harga pasar relatif terhadap nilai buku. Sudut pandang rasio lebih banyak berdasar pada sudut investor (calon investor), meskipun pihak manajemen juga berkepentingan terhadap rasio-rasio ini. Ada dua rasio pasar yang digunakan yaitu Price Earning Ratio (PER) dan Pembayaran Deviden (PD) (Mamduh M.Hanafi dan Abdul Halim, 2003 : 77). Salah satu fungsi dari akuntansi adalah melakukan pengukuran termasuk pengukuran prestasi, hasil usaha, laba maupun posisi keuangan. Pengukuran laba ini bukan saja penting untuk menentukan prestasi perusahaan tetapi juga penting sebagai informasi bagi pembagian laba, penentuan kebijakan investasi, dan pembagian hasil.

$\mathrm{H} 1 \mathrm{a}=$ Rasio keuangan Current Ratio berpengaruh terhadap laba yang akan datang.

$\mathrm{H} 1 \mathrm{~b}=$ Rasio keuangan Profitabilitas berpengaruh terhadap laba yang akan datang.

$\mathrm{H} 1 \mathrm{C}=$ Rasio keuangan Solvabilitas berpengaruh terhadap laba yang akan datang.

$\mathrm{H} 1 \mathrm{~d}=$ Rasio keuangan Aktivitas berpengaruh terhadap laba yang akan datang.

$\mathrm{H} 1 \mathrm{e}=$ Rasio keuangan Pasar berpengaruh terhadap laba yang akan datang.

$\mathrm{H} 2$ = Rasio keuangan secara bersama-sama berpengaruh terhadap laba yang akan datang.

\section{METODE PENELITIAN}

\section{Populasi}

Populasi adalah jumlah dari keseluruhan objek (satuan-satuan/individu-individu) yang karakteristiknya hendak diselidiki atau diduga (Subagyo, dkk 2005:93). Populasi yang digunakan dalam penelitian ini adalah seluruh perusahaan manufaktur yang terdaftar di Bursa Efek Indonesia pada periode 2010-2014.

Laporan keuangan yang dipakai adalah laporan keuangan yang berakhir pada tanggal 31 Desember 2010-2014. Metode atau teknik sampel dilakukan secara purposive ramdom sampling yaitu memilih sampel yang sesuai dengan kriteria-kriteria yang telah ditentukan.

\section{Sampel dan Teknik Sampling}


Sampel adalah sebagian dari populasi yang karakteristiknya hendak diselidiki, dan dianggap mewakili keseluruhan populasi (jumlahnya lebih sedikit dari pada populasi) (Suwarni, 2001). Perusahaan yang masuk dalam sampel dikategorikan sebagai berikut ini :

a. Perusahaan yang go public dari jenis industri manufaktur yang tercatat di BEJ selama Januari 2010 sampai dengan Desember 2014. Dalam arti bahwa saham yang tercatat pada tahun 2010 akan masih tercatat sampai dengan tahun 2014.

b. Saham-sahamnya aktif diperdagangkan di BEJ selama kurun waktu 2010-2014. Kriteria aktif diperdagangkan didasarkan pada surat edaran PT. Bursa Efek Jakarta No. SE-3/BEJ 11-1/5/1994, yaitu apabila frekuensi perdagangan selama 3 bulan sebanyak 75 kali atau lebih.

c. Menerbitkan laporan keuangan lengkap yang diperlukan dalam penelitian ini mulai tahun 2010-2014, serta dimuat dalam Index Capital Market Directionary (ICMD).

\section{Penggunaan variable}

Dalam penelitian ini variabel dibedakan menjadi dua yaitu :

1. Variabel Dependen ( $Y$ )

Variabel dependen adalah variabel yang menjadi perhatian utama dalam sebuah pengamatan (Mudrajad Kuncoro, 2003 : 42). Dalam penelitian ini laba di masa yang akan datang digunakan sebagai variabel dependen.

2. Variabel Independen (X1-X10)

Variabel independen adalah variabel yang dapat mempengaruhi perubahan variabel dependen dan mempunyai hubungan positif ataupun negatif bagi variabel dependen nantinya (Mudrajad Kuncoro, 2003 : 42). Dalam penelitian ini rasio keuangan digunakan sebagai variabel independen. Rasio keuangan yang digunakan berjumlah 10 rasio yang terdiri dari :

1. Rasio Lancar ( $R L$ ) adalah rasio untuk mengukur kemampuan perusahaan dalam membayar kewajiban finansial jangka pendek dengan menggunakan aktiva lancar ,Rumus rasio lancar $=\frac{\text { aktiva lancar }}{\text { hutang lancar }} \times 100 \%$

2. Rasio Quick (RQ) adalah rasio untuk mengukur kemampuan perusahaan dalam membyar kewajiban finansial jangka pendek dengan menggunakan aktiva lancar yang lebih liquid, rumus $=$ kas + efek $+\frac{\text { piutang }}{\text { hutang lancar }} \times 100 \%$

3. Rata-Rata Umur Piutang (RUP) rasio ini mengukur efisiensi pegolahan piutang perusahaan serta mennjukkan berapa lama waktu yang diperlukan untuk melunasi piutang atau merubah pitang menjadi kas. Rumus RUP = piutang : penjualan per hari $=$ pitang $\times 365$ : penjualan.

4. Perputaran Aktiva Tetap (PAT) rasio ini merupakan perbandingan antar penjualan dengan aktiva tetap. Rasio ini berguna untuk mengevaluasi kempuan perusahaan menggunakan aktivanya secara efektif serta meningkatkan pendapatan.

Rumus PAT $=\frac{\text { penjualan }}{\text { aktiva tetap }}$

5. Total Hutang terhadap Total Aset (THTA) rasio ini merupakan perbandingan antara hutang lancar dan hutang jangka pankang dan jumlah seluruh aktiva diketahui.

Rumus $=\frac{\text { total hutang }}{\text { total aktiva }} \times 100 \%$ 
6. Time Interest Earned (TIE) merupakan perbandingan antara laba bersih sebelum bunga dan pajak dengan beban bunga dan merupakan rasio ang mencerminkan besarnya jaminan keuangan untuk membayar bunga hutang jangka panjang.

Rumus $=\frac{\text { laba bersih sebelum bunga dan pajak }}{\text { beban bunga }}$

7. Profit Margin (PM) merupakan rasio yang digunakan untuk mengukur laba bersih sesudah pajak lalu dibandingkan dengan volume penjualan.

Rumus $=\frac{\text { laba setelah pajak }}{\text { total aktiva }} \times 100 \%$

8. Return On Asset (ROA) adalah salah satu bentuk dari rasio profabilitas untuk mengukur kemamouan perusahaan dalam menghasilkan laba dengan menggunakan total aktiva yang ada dan setelah biaya-biaya dikeluarkan dari analisis.

Rumus $=\frac{\text { laba bersih setelah pajak }}{\text { total aktiva }} x 100 \%$

9. Price Earning Ratio (PER) adalah rasio harga per Irmbar saham saat ini terhadap laba bersih perusahaan.

Rumus $=\frac{\text { harga per lembar saham }}{\text { laba perlembar saham }}$

10. Pembayaran Deviden (PD) jumlah deviden yang dbayarkan kepada pemegang saham relative terhadap jumlah total laba bersih perusahaan.

Rumus $=\frac{\text { deviden payout rsio }}{\text { deviden nett income }}$

\section{ANALISIS DATA}

\section{Statistik Deskriptif Perusahaan Sampel}

Penelitian ini menggunakan 30 perusahaan manufaktur, sampel yang diamati selama 6 tahun terakhir yaitu tahun 2010 sampai dengan tahun 2014. Pemilihan periode lima tahun terakhir dikarenakan perusahaan-perusahaan tersebut selama lima periode terakhir menunjukkan kenaikan yang cenderung baik dan mengeluarkan rasio pembayaran dividen dalam laporan keuangannya (www.idx.co.id).

\section{Deskripsi Data}

Menurut Singgih Santoso (2004) analisis statistik deskriptif bertujuan untuk mengetahui karakteristik data seperti nilai rata-rata, seberapa jauh data-data bervariasi (standar deviasi), nilai minimum dan maksimum data. Pengujian statistik deskriptif dapat dilihat pada tabel di bawah ini.

Tabel 4.1. Descriptive Data Statistics

\begin{tabular}{|l|r|r|r|r|r|}
\hline \multicolumn{7}{|c|}{ Descriptive Stati stics } \\
\hline X1_RL & N & Minimum & Maximum & \multicolumn{1}{c|}{ Mean } & Std. Dev iat ion \\
X2_RQ & 30 & .00 & 6.31 & 1.8150 & 1.33453 \\
X3_RUP & 27 & -.65 & .64 & -.0135 & .28087 \\
X4_PTA & 30 & 36.21 & 364.87 & 108.6093 & 77.99915 \\
X5_THTA & 30 & 4.07 & 11.69 & 7.6883 & 2.23438 \\
X6_TIE & 30 & -.71 & 2.06 & -.1945 & .47227 \\
X7_PM & 30 & .03 & 13.37 & 2.5821 & 3.68479 \\
X8_ROA & 30 & 20521.40 & $2 E+011$ & $1 \mathrm{E}+010$ & $4.627 \mathrm{E}+010$ \\
X9_PER & 30 & -2.39 & 1.60 & -1.1660 & .69440 \\
X10_DP & 30 & .04 & $1 \mathrm{E}+009$ & $4 \mathrm{E}+007$ & 243459062.2 \\
Y_LYAD & 30 & 260.00 & $3 \mathrm{E}+008$ & $2 \mathrm{E}+007$ & 67796080.16 \\
Valid N (list wise) & 30 & 4.27 & 11.34 & 7.0671 & 2.03085 \\
\hline
\end{tabular}

Sumber: data sekunder diolah, 2016 
Dari deskripsi di atas menunjukkan bahwa :

1). x1 Rasio Lancar (RL) nilai minimum 0,00 , nilai maximum 6,31 , mean 1,8150 , standar deviasi 1,33453.

2). x2 Rasio Quick (RQ) nilai minimum -0,65, nilai maximum 0,64, mean -0,0135, standar deviasi 0,28087.

3). x3 Rata-Rata Umur Piutang (RUP) nilai minimum 36,21, nilai maximum 364,87, mean 108,6093, standar deviasi 77,9.

4). x4 Perputaran Total Aktiva (PTA) nilai minimum 4,07, nilai maximum 11,69, mean 7,68, standar deviasi 2,23.

5). x5 Total Hutang Terhadap Total Aktiva (T.H.T.A) nilai minimum $-0,71$, nilai maximum 2,06, mean $-0,1945$, standar deviasi 0,47.

6). x6 Time Interest Earned (TIE) nilai minimum 0,03, nilai maximum 13,37, mean 2,58, standar deviasi 3,68.

7). x7 Proft Margin (PM) nilai minimum 20521,4, nilai maximum 200.000.000.000, mean 10.000.000.000, standar deviasi 46.270.000.000.000.

8). x8 Return On Assets (ROA) nilai minimum -2,39, nilai maximum 1,60, mean -1,1660, standar deviasi 0,69440.

9). x9 Price Earning Ratio (PER) nilai minimum 0,04, nilai maximum 1.000.000.000, mean 40.000.000, standar deviasi 243459062,2.

10). x10 Pembayaran Deviden (DP) nilai minimum 260, nilai maximum 300.000.000, mean 20.000.000, standar deviasi 67796080,16.

Y Laba yang akan datang (LYAD) nilai minimum 4,27, nilai maximum 11,34, mean 7,0671, standar deviasi 2,03085.

\section{ANALISIS DATA}

\section{Uji Asumsi Klasik}

Sebelum hasil analisis regresi yang diperoleh tersebut digunakan untuk menguji hipotesis, terlebih dahulu dilakukan pengujian asumsi klasik terhadap model regresi tersebut. Adapun uji asumsi klasik yang dilakukan dalam penelitian ini meliputi:

\section{Uji Normalitas}

Menurut Ghozali (2001), uji normalitas data digunakan untuk menguji apakah dalam model regresi, variabel terikat dan variabel bebas keduanya mempunyai distribusi normal ataukah tidak. Hasil pengujian normalitas data dapat dilihat pada gambar di bawah ini.

Grafik 4.1. Hasil Uji Normalitas Data

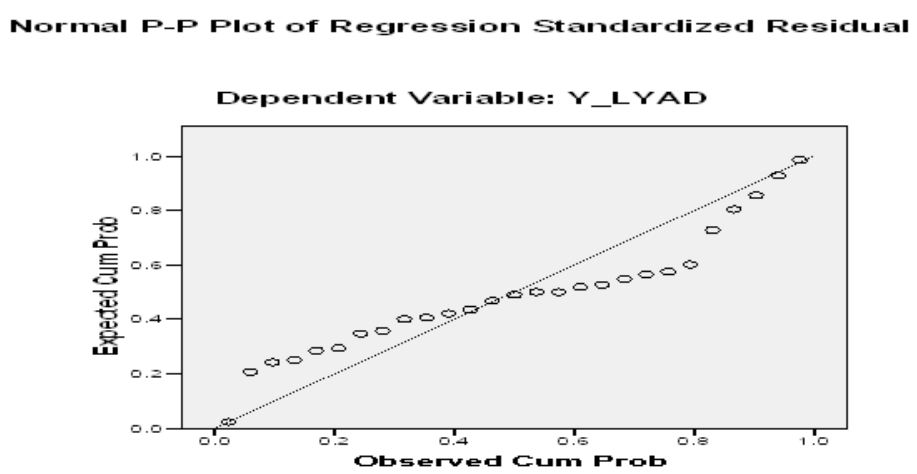

Sumber: data sekunder diolah 
Berdasarkan grafik di atas, terlihat titik-titik menyebar di sekitar garis diagonal, serta penyebarannya mengikuti arah garis diagonal. Hal ini berarti model regresi layak digunakan karena memenuhi asumsi normalitas.

\section{Uji Heteroskedastisitas}

Menurut Ghozali (2001), uji ini bertujuan untuk menguji apakah dalam model regresi terjadi ketidaksamaan variance dari residual satu pengamatan ke pengamatan yang lain. Jika variance dari residual satu pengamatan ke pengamatan yang lain tetap, maka disebut homoskedastisitas dan jika berbeda disebut heteroskedastisitas. Model regresi yang baik adalah yang homoskedastisitas atau tidak terjadi heteroskedastisitas. Uji heteroskedastisitas dapat dilihat dengan grafik plot (scatterplot) di mana penyebaran titik-titik yang ditimbulkan terbentuk secara acak, tidak membentuk sebuah pola tertentu serta arah penyebarannya berada di atas maupun di bawah angka 0 pada sumbu Y. Dengan demikian tidak terjadi gejala heteroskesdastisitas pada regresi ini, sehingga model regresi yang dilakukan layak dipakai untuk memprediksi kebijakan dividen berdasarkan variabel independennya. Tetapi tes heteroskedastisitas menggunakan scatterplot sangat lemah karena hanya mengandalkan analisis visual. Untuk mendapatkan kepastian perlu uji hipotesis yaitu menggunakan uji Glejser. Uji Glejser adalah uji hipotesis untuk mengetahui apakah sebuah model regresi memiliki indikasi heterokedastisitas dengan cara meregresi absolud residual.

Tabel 4.1 Hasil Uji Heteroskedastisitas

Coefficients $^{a}$

\begin{tabular}{|c|c|c|c|c|c|c|}
\hline \multirow[t]{2}{*}{ Mod } & & \multicolumn{2}{|c|}{ Unstandardized Coefficients } & Standardized & \multirow[t]{2}{*}{$\mathrm{T}$} & \multirow[t]{2}{*}{ Sig. } \\
\hline & & $\mathrm{B}$ & Std. Error & Beta & & \\
\hline \multirow{11}{*}{1} & (Constant) & $-1,010 \mathrm{E}-013$ & 1,406 & & ,000 & 1,000 \\
\hline & X1_RL & ,000 & 248 & ,000 &, 000 & 1,000 \\
\hline & $\mathrm{X} 2 \_\mathrm{RQ}$ & , 000 & 603 & ,000 & ,000 & 1,000 \\
\hline & X3_RUP & ,000 & 605 & ,000 & ,000 & 1,000 \\
\hline & X4_PTA & ,000 & 863 & ,000 & ,000 & 1,000 \\
\hline & X5_THTA & ,000 & ,550 & ,000 & ,000 & 1,000 \\
\hline & X6_TIE & , 000 & ,273 & ,000 & ,000 & 1,000 \\
\hline & X7_PM & ,000 & ,842 & ,000 & ,000 & 1,000 \\
\hline & X8_ROA & ,000 & 1,105 & ,000 & ,000 & 1,000 \\
\hline & X9_PER & ,000 & ,071 & ,000 & ,000 & 1,000 \\
\hline & X10_DP & ,000 & 104 & ,000 & ,000 & 1,000 \\
\hline
\end{tabular}

a. Dependent Variable: AbsRes

Sumber: data sekunder diolah, 2016

Dari output regresi nilai absolud diatas terlihat semua variabel indipenden tidak ada yang mempengaruhi nilai absolud dibuktikan dengan nilai sig 1,00>0,05 sehingga diputuskan tidak ada indikasi Heterokedastisitas

\section{Uji Multikolinearitas}

Menurut Ghozali (2001), uji multikolinearitas bertujuan untuk menguji apakah pada model regresi ditemukan adanya korelasi antar variabel bebas (independen). Hasil pengujian multikolinearitas dapat dilihat pada tabel di bawah ini. 
Tabel 4.2. Hasil Uji Multikolinearitas

\begin{tabular}{|c|c|c|c|c|c|c|c|c|c|c|c|}
\hline \multicolumn{12}{|c|}{ Coefficients $^{\mathrm{a}}$} \\
\hline \multirow[b]{2}{*}{ Mode } & & \multicolumn{2}{|c|}{$\begin{array}{l}\text { Unstandardized } \\
\text { Coefficients }\end{array}$} & \multirow{2}{*}{$\begin{array}{c}\text { Standardized } \\
\text { Coefficients }\end{array}$} & \multirow[b]{2}{*}{$t$} & \multirow[b]{2}{*}{ Sig. } & \multicolumn{3}{|c|}{ Correlations } & \multicolumn{2}{|c|}{ Collinearity Statistics } \\
\hline & & B & Std. Error & & & & Zero-order & Partial & Part & Tolerance & VIF \\
\hline 1 & (Constant) & 1.696 & .732 & & 2.316 & .034 & & & & & \\
\hline & X1_RL & .013 & .179 & .009 & .074 & .942 & .086 & .018 & .005 & .253 & 3.956 \\
\hline & X2_RQ & -.792 & .724 & -.113 & -1.094 & .290 & .099 & -264 & -.068 & .357 & 2.802 \\
\hline & X3_RUP & 5.27E-005 & .002 & .002 & .029 & .977 & -201 & .007 & .002 & .715 & 1.399 \\
\hline & X4_PTA & .866 & .071 & .923 & 12.134 & .000 & .917 & .950 & .749 & .658 & 1.520 \\
\hline & X5_THTA & -1.208 & .963 & -.103 & -1.254 & .228 & -.137 & -299 & -.077 & .565 & 1.769 \\
\hline & X6_TIE & -.112 & .039 & -206 & -2.839 & .012 & -.070 & -.579 & -.175 & .725 & 1.378 \\
\hline & X7_PM & 2.25E-012 & .000 & .053 & .689 & .501 & .536 & .170 & .043 & .640 & 1.563 \\
\hline & X8_ROA & 1.223 & .355 & .270 & 3.449 & .003 & .114 & .653 & .213 & .620 & 1.614 \\
\hline & X9_PER & $-3.8 \mathrm{E}-010$ & .000 & -.049 & -.780 & .447 & -.060 & -191 & -.048 & .963 & 1.039 \\
\hline & X10_DP & 2.32E-009 & .000 & .084 & 1.104 & .286 & .148 & .266 & .068 & .660 & 1.515 \\
\hline
\end{tabular}

a. Dependent Variable: Y_LYAD

Sumber: data sekunder diolah

Berdasarkan tabel di atas, diperoleh nilai tolerance untuk seluruh variable independent di atas $10 \%(0,10)$, sedangkan bila dilihat berdasarkan nilai VIF (Variance Inflation Faktor) masing-masing variabel mempunyai nilai di bawah nilai ketetapan yaitu kurang dari 10, artinya tidak ada multikolinearitas antar variabel bebas dalam model regresi. Sehingga model regresi layak digunakan untuk memprediksi laba yang akan datang berdasarkan masukan variabel bebas terhadap laba yang akan datang.

\section{Autokorelasi}

Menurut Ghozali (2001), uji autokorelasi bertujuan untuk menguji apakah dalam suatu model regresi linear ada korelasi antara kesalahan pengganggu pada periode $t$ dengan kesalahan pada periode t-1 (sebelumnya). Hasil pengujian autokorelasi dapat dilihat pada tabel di bawah ini.

Tabel 4.3. Hasil Uji Autokorelasi

\begin{tabular}{|c|c|c|}
\hline Model & $\mathrm{R}$ & Durbin-Watson \\
\hline 1 & 0,969 & 2,301 \\
\hline
\end{tabular}

Sumber: data sekunder diolah, 2014

Berdasarkan tabel di atas diperoleh nilai Durbin-Watson sebesar 2,301,. Nilai ini akan dibandingkan dengan DW tabel dengan jumlah sample 30 perusahaan, jumlah variabel bebas 10 dan tingkat kepercayaan $5 \%$ di dapat nilai batas bawah (dl) $=1,46$ dan batas atas $(\mathrm{du})=1,63$. Oleh karena nilai DW 2,301, berada di antara batas atas (du) $=1,63$ dan $(4-d u)=2,37$, maka dapat disimpulkan tidak terjadi autokorelasi.

Berdasarkan uji asumsi klasik di atas, dapat disimpulkan bahwa semua data yang digunakan dalam penelitian memenuhi semua asumsi klasik, sehingga model regresi yang digunakan layak untuk memprediksi laba yang akan datang berdasarkan masukan variabel bebas.

\section{Uji Hipotesis}

\section{Analisis Regresi Linier Berganda}

Menurut Sugiyono (2005), alat ini digunakan untuk mengetahui apakah satu variabel dipengaruhi oleh variabel lain, di mana variabel tersebut lebih dari satu. Dalam penelitian ini 
variabel independen $(X)$ sedangkan variabel laba yang akan datang sebagai variabel dependen $(\mathrm{Y})$.

Berdasarkan analisis regresi berganda dengan program SPSS for Windows diperoleh nilai koefisien parameter (beta), t-value dan sig sebagai berikut :

Tabel 4.4. Hasil Uji Regresi Berganda

\begin{tabular}{|c|c|c|c|c|c|c|c|c|c|c|c|}
\hline \multicolumn{12}{|c|}{ Coefficients } \\
\hline \multirow[b]{2}{*}{ Mode } & & \multicolumn{2}{|c|}{$\begin{array}{c}\text { Unstandardized } \\
\text { Coeff icients }\end{array}$} & \multirow{2}{*}{$\begin{array}{c}\text { Standardized } \\
\text { Coefficients } \\
\text { Beta }\end{array}$} & \multirow[b]{2}{*}{$t$} & \multirow[b]{2}{*}{ Sig. } & \multicolumn{3}{|c|}{ Correlations } & \multicolumn{2}{|c|}{ Collinearity Statistics } \\
\hline & & B & Std. Error & & & & Zero-order & Partial & Part & Tolerance & VIF \\
\hline \multirow[t]{11}{*}{1} & (Constant) & 1.696 & .732 & & 2.316 & .034 & & & & & \\
\hline & X1_RL & .013 & .179 & .009 & .074 & .942 & .086 & .018 & .005 & .253 & 3.956 \\
\hline & $X 2 \_R Q$ & -.792 & .724 & -.113 & -1.094 & .290 & .099 & -.264 & -.068 & .357 & 2.802 \\
\hline & X3_RUP & $5.27 \mathrm{E}-005$ & .002 & .002 & .029 & .977 & -201 & .007 & .002 & .715 & 1.399 \\
\hline & X4_PTA & .866 & .071 & .923 & 12.134 & .000 & .917 & .950 & .749 & .658 & 1.520 \\
\hline & X5_THTA & -1.208 & .963 & -.103 & -1.254 & .228 & -.137 & -.299 & -.077 & .565 & 1.769 \\
\hline & X6_TIE & -.112 & .039 & -.206 & -2.839 & .012 & -.070 & -.579 & -.175 & .725 & 1.378 \\
\hline & X7_PM & 2.25E-012 & .000 & .053 & .689 & .501 & .536 & .170 & .043 & .640 & 1.563 \\
\hline & X8_ROA & 1.223 & .355 & .270 & 3.449 & .003 & .114 & .653 & .213 & .620 & 1.614 \\
\hline & X9_PER & $-3.8 \mathrm{E}-010$ & .000 & -.049 & -.780 & .447 & -.060 & -191 & -.048 & .963 & 1.039 \\
\hline & X10_DP & 2.32E-009 & .000 & .084 & 1.104 & .286 & .148 & .266 & .068 & .660 & 1.515 \\
\hline
\end{tabular}

a. Dependent Variable: Y_LYAD

Sumber: data sekunder diolah, 2016

Dari tabel di atas diperoleh persamaan regresi berganda sebagai berikut :

$Y=1,696+0,013 X 1-0,792 X 2+0,000052 X 3+0,866 X 4-1,208 \times 5-0,112 X 6+$ $0,00000000000225 X 7+1,223 \times 8-0,00000000038 \times 9-0,00000000232 \times 10$

Persamaan regresi berganda di atas dapat diinterpretasikan sebagai berikut :

1. Konstanta sebesar 1,696 menunjukkan bahwa dalam keadaan variabel-variabel independen diasumsikan tidak mengalami perubahan (sama dengan nol) maka laba yang akan datang sebesar 1,696.

2. Koefisien regresi sebesar 0,013 pada $X 1$ menunjukkan bahwa apabila Rasio Lancar (RL) mengalami peningkatan sebesar 1 satuan ,maka laba yang akan datang akan mengalami peningkatan sebesar 0,013 satuan di mana variabel independen lainnya dianggap tetap. Nilai koefisien regresi yang positif menunjukkan bahwa rasio lancer mempunyai pengaruh yang positif atau searah terhadap laba yang akan datang.

3. Koefisien regresi sebesar 0,792 satuan pada X2 menunjukkan bahwa apabila Rasio Quick (RQ)mengalami peningkatan sebesar 1 satuan maka laba yang akan datang akan mengalami penurunan sebesar 0,792 satuan di mana variabel independen lainnya dianggap tetap. Nilai koefisien regresi yang negative menunjukkan bahwa Rasio Quick (RQ) mempunyai pengaruh yang negative atau berlawanan arah terhadap laba yang akan datang.

4. Koefisien regresi sebesar 0,000052 satuan pada X3 menunjukkan bahwa apabila RataRata Umur Piutang (RUP) mengalami peningkatan sebesar 1 satuan, maka laba yang akan datang akan mengalami peningkatan sebesar 0,000052 satuan di mana variabel independen lainnya dianggap tetap. Nilai koefisien regresi yang positif menunjukkan Rata-Rata Umur Piutang (RUP) bahwa mempunyai pengaruh yang positif atau searah terhadap laba yang akan datang. 
5. Koefisien regresi sebesar 0,866 satuan pada X4 menunjukkan bahwa apabila Perputaran Aktiva Tetap (PAT) mengalami peningkatan sebesar 1 satuan maka laba yang akan datang akan mengalami peningkatan sebesar 0,866 satuan di mana variabel independen lainnya dianggap tetap. Nilai koefisien regresi yang positif menunjukkan bahwa Perputaran Aktiva Tetap (PAT mempunyai pengaruh yang positif atau searah terhadap laba yang akan datang.

6. Koefisien regresi sebesar 1,208 satuan pada X5 menunjukkan bahwa apabila Total Hutang terhadap Total Aset (THTA) mengalami peningkatan sebesar 1 satuan maka laba yang akan datang akan mengalami penurunan sebesar 1,208 satuan di mana variabel independen lainnya dianggap tetap. Nilai koefisien regresi yang negative menunjukkan bahwa Total Hutang terhadap Total Aset (THTA) mempunyai pengaruh yang negative atau berlawanan arah terhadap laba yang akan datang.

7. Koefisien regresi sebesar 0,112 satuan pada X6 menunjukkan bahwa apabila Time Interest Earned (TIE) mengalami peningkatan sebesar 1 satuan maka laba yang akan datang akan mengalami penurunan sebesar 0,112 satuan di mana variabel independen lainnya dianggap tetap. Nilai koefisien regresi yang negative menunjukkan bahwa Time Interest Earned (TIE) mempunyai pengaruh yang negative atau berlawanan arah terhadap laba yang akan datang.

8. Koefisien regresi sebesar 0,00000000000225 satuan pada $X 7$ menunjukkan bahwa apabila Profit Margin (PM) mengalami peningkatan sebesar 1 satuan maka laba yang akan datang akan mengalami peningkatan sebesar 0,00000000000225 satuan di mana variabel independen lainnya dianggap tetap. Nilai koefisien regresi yang positif menunjukkan bahwa Profit Margin (PM) mempunyai pengaruh yang positif atau searah terhadap laba yang akan datang.

9. Koefisien regresi sebesar 1,223 satuan pada X8 menunjukkan bahwa apabila Return On Asset (ROA) mengalami peningkatan sebesar 1 satuan, maka laba yang akan datang akan mengalami peningkatan sebesar 1,223 satuan di mana variabel independen lainnya dianggap tetap. Nilai koefisien regresi yang positif menunjukkan bahwa Return On Asset (ROA) mempunyai pengaruh yang positif atau searah terhadap laba yang akan datang

10.Koefisien regresi sebesar 0,00000000038 satuan pada X9 menunjukkan bahwa apabila Price Earning Ratio (PER) mengalami peningkatan sebesar 1 satuan maka laba yang akan datang akan mengalami penurunan sebesar 0,00000000038 satuan di mana variabel independen lainnya dianggap tetap. Nilai koefisien regresi yang negative menunjukkan bahwa Price Earning Ratio (PER) mempunyai pengaruh yang negative atau berlawanan arah terhadap laba yang akan datang.

11. Koefisien regresi sebesar 0,00000000232 satuan pada X10 menunjukkan bahwa apabila Pembayaran Deviden (PD).mengalami peningkatan sebesar 1 satuan maka laba yang akan datang akan mengalami peningkatan sebesar 0,00000000232 satuan di mana variabel independen negative lainnya dianggap tetap. Nilai koefisien regresi yang positif menunjukkan bahwa Pembayaran Deviden (PD).mempunyai pengaruh yang positif atau searah terhadap laba yang akan datang.

\section{Uji Statistik F}


Menurut Ghozali (2001), uji statistik F pada dasarnya menunjukkan apakah semua variabel bebas yang dimasukkan dalam model regresi mempunyai pengaruh secara bersama-sama terhadap variabel terikat/dependen. Hasil uji statistik F dapat dilihat pada tabel di bawah ini.

Tabel 4.5. Hasil Uji F

\begin{tabular}{|ll|r|r|r|r|r|}
\multicolumn{7}{|c|}{ ANOV A $^{\mathbf{b}}$} \\
Model & & Sum of & & & & \\
\hline 1 & & Squares & df & Mean Square & F & Sig. \\
& Regression & 94.597 & 10 & 9.460 & 24.654 & $.000^{\mathrm{a}}$ \\
& Residual & 6.139 & 16 & .384 & & \\
& Total & 100.736 & 26 & & & \\
\hline
\end{tabular}

a. Predictors: (Constant), X10_DP, X7_PM, X9_PER, X8_ROA, X2_RQ, X5_THTA, X3_ RUP, X6_TIE, X4_PTA, X1_RL

b. Dependent Variable: Y_LYAD

Sumber: data sekunder diolah.

Berdasarkan tabel di atas (uji Anova), diperoleh nilai $F$ hitung sebesar 24,654 dengan tingkat probabilitas 0,000 (signifikansi). Karena probabilitas lebih kecil dari 0,05 dan nilai $F$ lebih besar dari 1,6, maka model regresi dapat digunakan untuk memprediksi laba yang akan datang atau dengan kata lain bahwa variable $X$ secara bersama-sama berpengaruh signfikan terhadap laba yang akan datang.

\section{Uji Koefisien Determinasi}

Menurut Ghozali (2001), koefisien determinasi (R2) pada intinya mengukur seberapa jauh kemampuan model dalam menerangkan variasi variabel dependen. Nilai koefisien determinasi adalah di antara nol dan satu. Uji koefisien determinasi dapat dilihat pada tabel di bawah ini.

Tabel4.6. Hasil Uji Koefisien Determinasi

Model Summary
\begin{tabular}{|c|r|r|r|r|c|}
\hline Model & R & R Square & $\begin{array}{c}\text { Adjusted } \\
\text { R Square }\end{array}$ & $\begin{array}{c}\text { Std. Error of } \\
\text { the Estimate }\end{array}$ & $\begin{array}{c}\text { Durbin- } \\
\text { Watson }\end{array}$ \\
\hline 1 & $.969^{\mathrm{a}}$ & .939 & .901 & .61944 & 2.301 \\
\hline
\end{tabular}
a. Predictors: (Constant), X10_DP, X7_PM, X9_PER, X8_ROA, X2_RQ, X5_
THTA, X3_RUP, X6_TIE, X4_PTA, X1_RL
b. Dependent Variable: Y_LYAD

Sumber: data sekunder diolah

Berdasarkan tabel di atas, besarnya nilai Adjusted R2 adalah 0,901. hal ini berarti 90,1\% variasi laba yang akan datang bisa dijelaskan oleh variasi dari sepuluh variabel independen. Sedangkan sisanya $6,1 \%(100 \%-90,1 \%)$ dijelaskan oleh faktor-faktor yang lain di luar model regresi.

Berdasarkan tabel Hasil Uji Regresi Berganda maka diperoleh uji t sebagai berikut :

1. RL tidak signifikan karena $>5 \%$

2. RQ tidak signifikan karena $>5 \%$

3. RUP tidak signifikan karena $>5 \%$

4. PTA signifikan karena $>5 \%$

5. THTA tidak signifikan karena $>5 \%$ 
6. TIE signifikan karena $>5 \%$

7. PM tidak signifikan karena $>5 \%$

8. ROA signifikan karena $>5 \%$

9. PER tidak signifikan karena $>5 \%$

10. DP tidak signifikan karena $>5 \%$

\section{KESIMPULAN}

a. Konstanta sebesar 1,696 menunjukkan bahwa dalam keadaan variabel-variabel independen diasumsikan tidak mengalami perubahan (sama dengan nol) maka laba yang akan datang sebesar 1,696.

b. Koefisien regresi sebesar 0,866 satuan pada X4 menunjukkan bahwa apabila Perputaran Aktiva Tetap (PAT) mengalami peningkatan sebesar 1 satuan maka laba yang akan datang akan mengalami peningkatan sebesar 0,866 satuan di mana variabel independen lainnya dianggap tetap. Nilai koefisien regresi yang positif menunjukkan bahwa Perputaran Aktiva Tetap (PAT) mempunyai pengaruh yang positif atau searah terhadap laba yang akan datang.

c. Koefisien regresi sebesar $-0,112$ satuan pada X6 menunjukkan bahwa apabila Time Interest Earned (TIE) mengalami peningkatan sebesar 1 satuan maka laba yang akan datang akan mengalami penurunan sebesar 0,112 satuan di mana variabel independen lainnya dianggap tetap. Nilai koefisien regresi yang negative menunjukkan bahwa Time Interest Earned (TIE) mempunyai pengaruh yang negative atau berlawanan arah terhadap laba yang akan datang.

d. Koefisien regresi sebesar 1,223 satuan pada X8 menunjukkan bahwa apabila Return On Asset (ROA) mengalami peningkatan sebesar 1 satuan, maka laba yang akan datang akan mengalami peningkatan sebesar 1,223 satuan di mana variabel independen lainnya dianggap tetap. Nilai koefisien regresi yang positif menunjukkan bahwa Return On Asset (ROA) mempunyai pengaruh yang positif atau searah terhadap laba yang akan datang

\section{SARAN PENELITIAN YANG AKAN DATANG}

Jika dilihat analisis diatas dari ke sepuluh rasio keuangan didapat 3 rasio yang paling singnifikan terhadap laba dimasa datang pada perusahaan manufaktur yang terdaftar di Bursa Efek Indonesia (BEI) selama periode 2010-2014. Rasio tersebut adalah Perputaran Aktiva tetap (PAT), Time Interest Earned (TIE),return On Asset (ROA), maka sebaiknya para investor memberikan kredit khusus terhadap ketiga rasio tersebut sebelum menentukan kebijakan investasinya di Bursa Efek Indonesia (BEI).

\section{DAFTAR PUSTAKA}

Ekawati, Erni. 2004. Tingkat Pertumbuhan dan Keuntungan Akuntansi di Dalam Strategi Value Creation Perusahaan. SNA VII, Denpasar Bali, 2-3 Desember 2004.

Endro, Agus, Suwarno. 2004. Manfaat Rasio Keuangan dalam Memprediksi Perubahan Laba (Studi Empiris terhadap Perusahaan Manufaktur Go Publik di Bursa Efek Jakarta). Jurnal Akuntansi dan Keuangan, Vol.3, No.2, September 2004 : 127-152.

Financial Accounting Standards Board (FASB). 1987. Statement of Financial Accounting Concept, No $1-6$ 
Hamzah, Ardi. 2007. Analisa Rasio Likuiditas, Profitabilitas, Aktivitas dan Solvabilitas terhadap Capital Gain (Loss) dan Deviden pada Perusahaan Manufaktur di Bursa efek Jakarta. Jurnal Ilmiah Akuntansi, Vol.6, No.1, Mei 2007 : 22-31.

Harahap, Sofyan Syafri. 2004. Analisis Kritis Atas Laporan Keuangan. Jakarta : Raja. Grafindo Persada.

Hendriksen, E. S., dan M. Breda. 1992. Accounting Theory. 5th Edition. USA: Richard D Irwin Inc.

Husnan, Suad. 2001. Manajemen Keuangan Teori Dan Penerapan (Keputusan Jangka Pendek) Buku 2 Edisi 4 Cetakan Pertama. Yogyakarta: BPFE.

Ikatan Akuntan Indonesia. 2002. Standar Akuntansi Keuangan. Jakarta: Salemba Empat.

Indriati Wijayanti, Y. Anni Aryani, dan Doddy Setiawan. 2005. Kemampuan Informasi Keuangan Memprediksi Perubahan Laba. Jurnal Bisnis dan Manajemen, Vol.5, No.1, 2005, : 173-182.

Kuncoro, Mudrajad. 2003. Metode Riset untuk Bisnis dan Ekonomi. Jakarta : Erlangga.

Kurniawati, Indah. 2001. Perbandingan Rasio-Rasio Keuangan pada Perusahaan Besar dan Perusahaan Kecil di Malaysia, Singapura, dan Taiwan. Jurnal Akuntansi dan Bisnis, Vol.1, No.1, Agustus 2007: 13-23.

Mamduh M. Hanafi dan Abdul Halim. 2003. Analisis Laporan Keuangan. Edisi Revisi. Yogyakarta: Penerbit (UPP) AMP YKPN.

Mamduh M. Hanafi dan Abdul Halim. 2005. Analisis Laporan Keuangan, Edisi. Kedua. Yogyakarta : STIE YKPN.

Meythi. 2007. Rasio Keuangan yang Paling Baik sebagai Prediktor Risiko Sistematik : Suatu Studi Empiris pada Perusahaan Manufaktur yang Terdaftar di Bursa Efek Jakarta. Jurnal Ilmiah Akuntansi, Vol.6, No.2, November 2007 : 1-23.

Munawir. 2004. Analisa Laporan Keuangan, Edisi Keempat, Cetakan Ketigabelas. Yogyakarta: Liberty.

Nurjanti Takarini dan Erni Ekawati. 2003. Analisis Rasio Keuangan dalam Memprediksi Perubahan Laba pada Perusahaan Manufaktur di Pasar Modal Indonesia. Ventura, Vol.6, No.3, Desember 2003.

Rietvield, 1993. Masalah Pokok Dalam Regresi Berganda. Yogyakarta: Andi Offset.

Subagyo dkk. 2005. Metode Penelitian dalam Teori dan Praktek. Jakarta: Rineka.

Sutopo, Bambang. 2005. Perubahan Laba, Perubahan Deviden, dan Perubahan Laba yang Akan Datang. Jurnal Bisnis dan Manajemen, Vol.5, No.2, 2005 : 123-130. 
Syafri, Syofan, Harahap, B.S.Ac.,S.E,Akuntan.,M.S.Ac.,Ph.D. 2004. Teori Akuntansi. Jakarta: Penerbit PT.Raja Grafindo Persada.

Tetet Fitrijanti dan Jogiyanto Hartono M. 2002. Set Kesempatan Investasi : Konstruksi Proksi dan Analisis Hubungannya dengan Kebijakan Pendanaan dan Deviden. Jurnal Riset Akuntansi Indonesia, Vol.5, No.1, Januari $2002: 35-63$.

Warsono. 2001. Manajemen Keuangan, Edisi Pertama, Cetakan Pertama. Malang: UMM Press.

Weston, Fred, J,. dan Brigham, F. Eugene. 1990. Manajemen Keuangan, Edisi Ketujuh, Jilid Dua. Jakarta: Erlangga. 